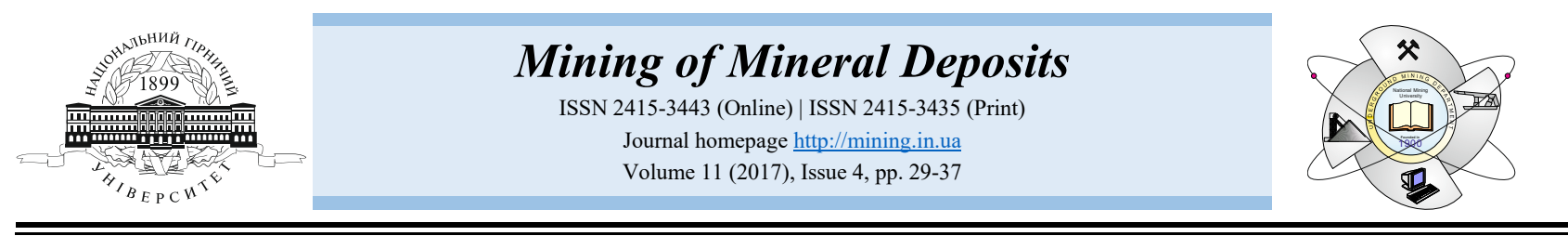

UDC 620.98

https://doi.org/10.15407/mining11.04.029

\title{
EVALUATION OF SOME RENEWABLE ENERGY TECHNOLOGIES
}

\author{
R. $\mathrm{Basu}^{1,2^{*}}$ \\ ${ }^{I}$ Mechanical Engineering Department, Adarsha Institute of Technology, Bangalore, India \\ ${ }^{2}$ Visvesvaraya Technological University, Belagavi, India \\ *Corresponding author: e-mail raulbasu@gmail.com, tel. +918026541874, fax:+918026542790
}

\section{ОЦНКА ДЕЯКИХ ТЕХНОЛОГІЙ ВИРОБНИЦТВА ВІДНОВЛЮВАЛЬНОЇ ЕНЕРГЕТИКИ}

\author{
P. Басу ${ }^{1,2^{*}}$ \\ ${ }^{1}$ Кафедра машинобудування, Адаршський технологічний інститут, Бангалор, Індія \\ ${ }^{2}$ Вісвесварайський технологічний університет, Белгаум, Індія \\ *Biдповідальний aвтор: e-mail raulbasu@gmail.com, тел. +918026541874, факс: +918026542790
}

\begin{abstract}
Purpose. The study aims to outline and compare various renewable energy alternatives in view of the global warming crisis and depletion of fossil fuels which cause emissions of carbon dioxide. Carbon dioxide is a major source of pollution and is an absorbent for radiation.

Methods. Literature surveys and analysis of benefits and drawbacks of the competing technologies should include the capital costs, running costs and carbon footprint. Liquid fuels have high energy to weight ratio compare to say solar panels or thermal absorbers, but what is neglected is the large refinery and other processing machinery behind the liquid fuel which is adding to the carbon footprint.

Findings. Producer gas and bacterial engines are suggested as possible pollution reducing and cost effective methods for power generation. Coal, biomass, geothermal and hydroelectric have the lowest running cost, but carbon footprint cost is neglected. Solar chimneys, with low mechanical efficiency have low running costs, and no pollution. Modification of internal combustion engines to use producer gas and alcohol may reduce overall carbon footprint.

Originality. Many researches focus on energy and mechanical efficiency. Bacterial engines have yet to be fully developed, and these are wonderful chemical factories but not understood in terms of classical thermodynamics. For all technologies, return on investment is more appropriate since capital costs are also included, which are neglected in mechanical efficiency calculations.

Practical implications. Depletion of forest cover which acts as a greenhouse gas sink contributes to global warming. Worldwide, million of cars with internal combustion engines consuming petroleum, if converted to alternative fuels, can help in reducing the carbon gas emissions and ultimately to a slowdown in the global warming rate.
\end{abstract}

Keywords: producer gas, biogas, global warming, carbon footprint, efficiency

\section{INTRODUCTION}

Natural sources of power such as the use of wind, solar heating and drying, and hydropower have been commonplace in many countries for centuries. It is only in the past decade or two that the global concern has mounted with concerns for the global environment and the future of the planet, with unfortunate visible effects on the atmosphere and effects on climate worldwide. An example is the shrinking of glaciers worldwide, the shrinking of the polar icecaps and rising sea levels, resulting in worldwide calamities like tsunamis, earthquakes and cyclones. These considerations and aspects have recently been incorporated into the national plans of many countries; many global organiza- tions and Non-Governmental Organizations (NGO) have also got into the picture. It is now common to talk about carbon credits and monetary equivalents that can be traded and used to offset production of pollutants by nations.

According to a recent study (Carey, 2012), $\mathrm{CO}_{2}$ increase due to deforestation accounts for more $\mathrm{CO}_{2}$ than all vehicles worldwide. Four wheelers produce $14 \%$ of the global carbon emissions, while upward of $15 \%$ is from deforestation. According to the Environmental Defense Fund (EDF), 32 million tons of tropical rain forests were cut down each year from 2000 - 2009. Forest clearing will put another 200 billion tons of carbon monoxide in the air in coming decades. 
Natural organic fuels are a major power source for developing nations. Biomass continues as a source of cheap and polluting energy in rural areas, especially for below poverty line populations. The scarcity of urban dwelling spaces also forces many people to occupy fringe forest areas or collect biomass illegally from forests and destroy green cover in urban spaces. On the other hand, many people migrate to the large urban centers hoping to find work, occupying slums. The strain on the civic amenities due to the extra settlements on pavements and established slums causes problems like power outages, water shortage and epidemics. The problem of urban waste management is a difficult one. In addition, as it is now noticed, air pollution in the form of carbon emissions and methane cause global warming by the greenhouse effect.

Profits from timber, charcoal, pasture and cropland induce people to cut down forests because of easy availability and low cost. The United Nations Programme on Reducing Emissions from Deforestation and Forest Degradation (UN-REDD Programme) provides incentives to people who care for forests and manage sustainably while still being able to benefit economically through a system of pollution credits. Brazil adopted REDD and slowed deforestation $40 \%$ since 2008 and is on the way to $80 \%$ reduction by 2020 . India is not a member, though Bangladesh, Nepal, Sri Lanka, Pakistan, Myanmar have joined. Brazil is a major player in the sustainable development field, having already introduced biofuels and ethyl alcohol as motor fuel.

Pollution figures for India indicate $3000 \mathrm{lb} /$ capita in 2007, China at $10500 \mathrm{lb} /$ capita, and US at $42500 \mathrm{lb} /$ capita. India has the worst air pollution record in the world due to the large number of two wheelers and retrofitted compressed natural gas $(\mathrm{CNG})$ kits causing 30\% more methane emissions together with emission from coal burning power plants.

It is well known that poverty and the degradation of the environment are closely linked, hence improvement of living standards and natural resource management at the grass roots level is essential in any strategy to reclaim the environment. The poor rely heavily on natural resources.

In addition, diversion of common lands used historically for other public projects and schemes deprives the poor of their common resources, forcing them to encroach on forest land. The dominant sources of pollution in India are domestic burning and two stroke emissions (De Laat, de Gouw, Lelieveld, \& Hansel, 2001).

2012 was to be the International Year of Sustainable Energy for all, according to the UN. The climate food agricultural linkage is emphasized in relation to fossil fuel inputs. For a country like India which has a sizeable rural population subsisting on agriculture and depending on livestock, biogas has provided a viable source of energy and has been subsidized by various Governmental incentives and schemes. The problem underlying such efforts is the extreme poverty in which the majority of the rural populace lives. In fact, traditional village lifestyles dictate the use of cow dung for cooking with fire, smearing cow dung solution on the ground, placing cow dung cakes on the walls and so on. Till recently it was difficult to get people to use cow dung as a crop fertilizer, and the major fertilizer companies have made hay of this fact.
Biogas has certain desirable qualities with regard to the environment:

- it is low cost and low tech and requires low investment and capital;

- uses waste products and does not require chemical additives;

- produces a sludge which can be used further as a fertilizer;

- it can contribute to treatment of domestic and municipal wastes.

Most of the subsidies given by State and NonGovernmental Organizations (NGO) so far have been on biogas, whereas producer gas has been neglected in the resurgence of renewable energy sources.

Apart from the payoffs in secondary energy generation (i.e., after methane has been recovered from biomass by bacterial action), the remaining bio matter/biomass residue which consists of $\mathrm{C}$ and $\mathrm{N}$ with $\mathrm{H}_{2} \mathrm{O}$ is capable of further reduction into "producer gas". A further advantage is in reducing the biologically active component which may consist of any harmful bacteria, mosquito larvae and viruses and other vectors into inert form. The resultant solid matter is highly concentrated with nitrogenous matter and thus suitable as fertilizer for agricultural usage. Although the initial biomatter which may be dung, composted material and waste food matter can be used and is frequently applied directly on the fields, the result of producer gas reduction is more inert and as useful if not more suitable as a fertilizer. Besides, the decomposition of animal dung in the open after being applied as a surface additive for crops yields large amounts of methane and adds to the pollutants in the atmosphere, besides contributing to vector propagation like flies and mosquitoes.

In Ghana, West Africa, one of the main reasons of development of biogas is to treat sewage which is largely untreated and run off into the bush outside the villages, in order to improve sanitation and reduce attendant risks of epidemics and diseases endemic to Africa (Bensah \& Brew-Hammond, 2008).

\section{INTERNATIONAL EFFORTS IN THE AREA OF RENEWABLE ENERGY}

Serious efforts have been made in the island nations of the Indian and Pacific Oceans, like the Philippines and Sri Lanka, subsidized by the International agencies like UN. In Africa, countries like Ghana have taken up biogas projects at a national level in their National Strategic Planning. According to a recent survey (Bensah \& BrewHammond, 2008), the focus in Ghana has shifted from energy to sanitation, with construction of bio-toilets. The aim is to treat human wastes to a level where they can be safely discharged into drains. The remaining sludge is used as fertilizer.

In the Philippines, GEMCOR had set up gasifiers using coconut shell charcoal, resulting in cheap gas at lower rates than from wood or biomass. Boats have been fitted with engines running on producer gas (Mahin, 1983).

A number of raw materials have been researched for producer gas, including coconut, sugar cane bagasse, rice husks, corn cobs, coffee bean husks, peanut shells, cotton gin trash and stalks. The list could use organic trash, which has been reported in the recent 
issue of Scientific American (Wald, 2010). Third world cities with their large slums and attendant sanitation problems could take a leaf from these efforts initiated by India's neighbors.

During times of petrol scarcity as in the last world war, engines were developed to run on coal gas and gas from wood, which would be towed behind the vehicles. A survey was done by the Food and Agriculture Organization of the United Nations (FAO of the UN) in the 1970's and the results were published as a paper (Wood Gas as Engine Fuel, 1986).

Photovoltaic energy has also been looked at in detail in the context of agricultural and rural development. The life cycle and quality factors for such sources have been estimated (Campen, Guidi, \& Best, 2000).

\section{PRIMARY REACTIONS AND PRODUCTS FROM BIOMASS GASIFICATION}

\subsection{Basic data}

The gaseous products from carbon biomass are $\mathrm{CO}$, $\mathrm{CO}_{2}, \mathrm{H}_{2}, \mathrm{CH}_{4}, \mathrm{~N}_{2}, \mathrm{H}_{2} \mathrm{O}$. Trace amounts of higher hydrocarbons are present also. Schematic of gasification process is presented in Figure 1.

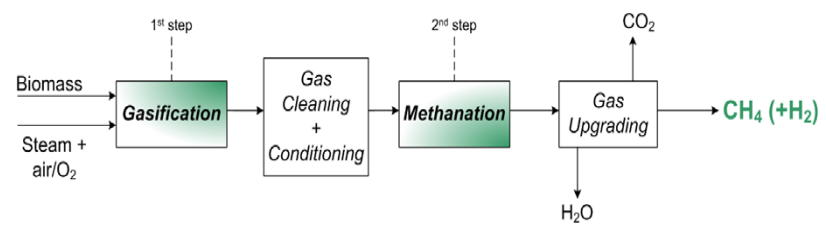

Figure 1. Schematic of gasification process

The basic reactions involve the steam reaction on carbon with limited oxygen:

$4 \mathrm{C}+2 \mathrm{H}_{2}+2 \mathrm{O}_{2} \rightarrow 4 \mathrm{CO}+4 \mathrm{H}+\mathrm{O}_{2}$

$2 \mathrm{CO}+\mathrm{O}_{2} \rightarrow 2 \mathrm{CO}_{2}$.

Also there are sub reactions of $\mathrm{C}$ with $\mathrm{H}, \mathrm{H}_{2}$ and $\mathrm{H}_{2}$, similarly with $\mathrm{CO}$ and $\mathrm{H}$ :

- pyrolysis/gasification:

$$
\begin{aligned}
& \mathrm{C}_{x} \mathrm{H}_{y} \mathrm{O}_{z}+a \mathrm{H}_{2} \mathrm{O} / b \mathrm{O}_{2} \rightarrow c \mathrm{CO}+d \mathrm{H}_{2}+e \mathrm{CO}_{2}+ \\
& +f \mathrm{CH}_{4}+g \mathrm{C}_{2}^{-4}+h \text { Tars }+i \mathrm{C}(s) ; \\
& \quad \text { - carbon gasification: } \\
& \mathrm{C}+\alpha \mathrm{H}_{2} \mathrm{O} / \beta \mathrm{CO}_{2} \rightarrow \gamma \mathrm{CO}+\delta \mathrm{H}_{2} ; \\
& \quad-\text { methanation: } \\
& \mathrm{CO}+3 \mathrm{H}_{2} \leftrightarrow \mathrm{CH}_{4}+\mathrm{H}_{2} \mathrm{O} ; \\
& \quad-\text { water-gas shift: } \\
& \mathrm{CO}+\mathrm{H}_{2} \mathrm{O} \leftrightarrow \mathrm{CO}_{2}+\mathrm{H}_{2} ; \\
& \quad-\text { steam reforming: } \\
& \mathrm{C}_{x} \mathrm{H}_{y}+x \mathrm{H}_{2} \mathrm{O} \rightarrow x \mathrm{CO}+(y / 2+x) \mathrm{H}_{2} .
\end{aligned}
$$

These reactions need the addition of heat which is supplied by burning additional raw material, and a supply of steam.

\subsection{Use in engines}

Strong interests in the petroleum and automotive industry have resisted and thwarted attempts to develop alternative designs and implementation of these in industry. However, modification of engines to use producer gas is not difficult, provided one understands the nature of the combustion and power cycle in the internal combustion engine. Basically, one cannot run the engine at a speed beyond the rate at which the fuel gas ignites and burns (flame velocity). In addition, the compression and air/fuel ratio are important. If too high a compression results, there is possibility of the gas igniting spontaneously, (knocking), which would damage the engine. Producer gas is capable of higher octane numbers than petrol, (octane number being a measure of the compression ratio at which detonation occurs). As a result, higher engine thermal efficiencies can be achieved with producer gas. Further refinements are possible but may need more research. One such possibility is to use regeneration and reheat as in the Rankine cycle.

Some studies have appeared on the use of producer gas in IC engines of $1000 \mathrm{KW}$ capacity (Sridhar et al., 2005).

\subsection{Producer gas for power generation}

$1 \mathrm{~kg}$ air-dry wood $(15-20 \% \mathrm{mc})$ gives about $2.3 \mathrm{~m}^{3}$ of gas; 1 litre petrol $=2.5$ to $3 \mathrm{~kg}$ wood; 1 litre diesel $=3$ to $3.5 \mathrm{~kg}$ wood; $1 \mathrm{kWh}$ requires 1 to $1.3 \mathrm{~kg}$ charcoal, 2 to $4 \mathrm{~kg}$ woodchips or 2.4 to $3.2 \mathrm{~kg}$ rice husk.

Feasibility and viability of a gasifier project depends on many factors, including cost of fuel, labour costs, money and finance, design life, value of the energy produced, cost of disposal of the residue, and value of the sludge for fertilizer. Further benefits are there when the electricity if generated can be sold to the grid.

The existence of a national energy programme and incorporation of such schemes into the development plans at state and national level would enhance such energy schemes.

At present the focus has been blurred by the large corporations battling it out for offshore oil rights, trying to sell cheap gas guzzling cars to the public, the conflicts (oil generated) in the middle east, and other political agendas. The attendant benefits of health and sanitation have been almost ignored in the energy plans at the higher levels.

In Tanzania, a programme for design of gasifiers for maize mills in rural areas was taken up by the Small Industries Development Organisation and the Nederlands Twente University (Mahin, 1983). A similar system was developed at Chulalongkorn University in Thailand. In El Salvador, with GEKA of Karlsruhe, coffee bean husks are burnt and the gas mixture fed to further dry coffee beans. In Valdosta, Georgia and Auburn, Alabama peanut shells have been used to give heat for drying. In Asia, rice husks are very commonly available as a byproduct, but according to the FAO in 1975, no mill existed which used steam produced by husk fired boilers. India and Thailand directly used rice husks as a form of boiler heat fuel, with some other countries also following suit. Parboiled rice in India is made mostly (50\% usage) by husk fired boilers, with some mills in Sri Lanka, Guyana, and Italy doing the same. The Govt of Malaysia had given funds for development of two pilot 
plants at rice mills using one ton of rice husks per hour. Electric power output of about $350 \mathrm{KW} /$ hour has been obtained in 1983 (Mahin, 1983).

\subsection{Drawbacks of producer and syngas}

Many engines and gas turbines being used for power generation are now using syngas and producer gas. It appears that while natural gas has $3 \%$ water content, syngas has about $18 \%$ water content which creates degradation and corrosion problems in the metal parts of these engines.

\subsection{Overall efficiency and economic analysis of the scheme}

Since producer gas production requires heat and steam production as input, there is an expenditure of energy involved which debits from the overall total of energy. The heating can be obtained by diverting part of the biogas obtained in the primary digestion stage to be used for heating and producing steam and high temperatures in gasifying the sludge residue for Producer gas. Alternatively, dried biomass used for the initial biogas production could be ignited and used for the secondary producer gas stage. So far, no study has been done on the efficiency and economics of the scheme. Producer gas was used to run a modified internal combustion engine (Sridhar et al., 2005), with reasonable results.

\subsection{Improvement of efficiency by cogeneration and regeneration}

Basically, the work done is the area under the $\mathrm{P}-\mathrm{V}$ curve, so any increase in the area implies an increase in the work obtainable within the input and output temperatures. Figure 2 shows the effect of regeneration, (applying some exhaust heat to heat the incoming fluid before the main cycle), similar to the Rankine cycle principle used commonly in the steam turbine technology.

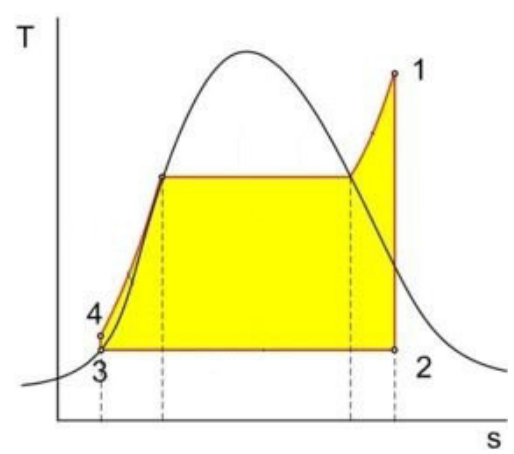

Figure 2. Increase of working area under $P-V$ curve for Rankine cycle

\subsection{Improvements by hybridisation}

A combination of gasification and solid fuel cell was examined by F.P. Nagel (2008) where solid oxide fuel cell (SOFC) was operated with producer gas.

A comparison of various SOFC schemes is given in the Table 1.

It was claimed that compared to methane, dilution of producer gas reduced the output of the SOFC (Fig. 3).

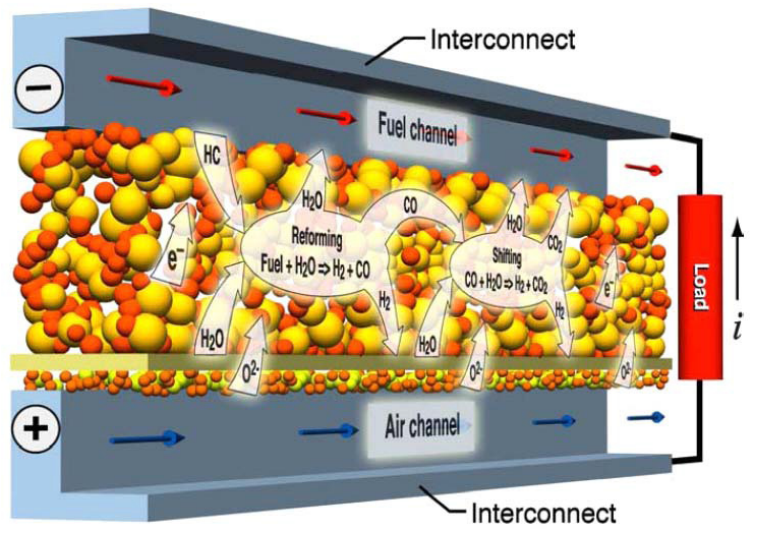

Figure 3. Working principle of an internally reforming anode supported SOFC (Nagel, 2008)

\section{IMPROVEMENTS BY USING STIRLING AND BRAYTON CYCLES}

It can be demonstrated that theoretical efficiency of the Stirling and Brayton cycles is the same as the Carnot efficiency and hence any power generator based on these cycles must have the highest efficiencies. Stirling was one of the first engines used during the industrial revolution, predating the internal combustion engine, and could use any type of fuel as it was externally heated. It is now making a comeback, especially amongst submarine applications for its silent operation, and in space application for low temperature differential engines (NASA). The same considerations of improvement of efficiency by regeneration apply here, and an important part of any Stirling engine is the regenerator and heat exchanger. By contrast, the Solar chimney has one of the lowest over all efficiencies, in terms of the conversion of incident solar energy. It has however been attempted in a number of countries, and a few references are given for illustration. Spain was one of the first countries to apply the technology (Santos Bernardes, 2010), after which Algeria, Egypt, Jordan have also attempted the technology with pilot plants. The drawback for the Solar chimney is high capital cost. A recent attempt using a flexible floating chimney has been reported from Greece, which claims to avoid wind loads (Christos, 2010) (Fig. 4). Data from studies show that the overall efficiency of the chimney is around $1 \%$ (i.e. of the incoming solar energy, $1 \%$ is converted to usable energy).

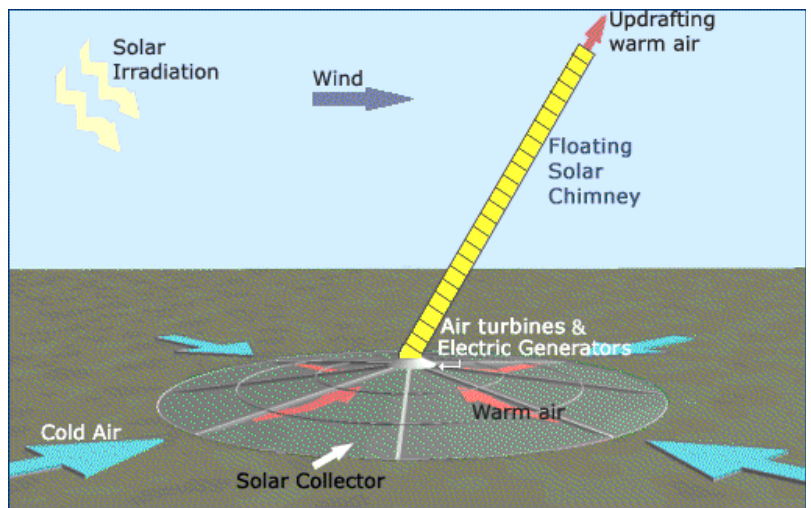

Figure 4. Floating solar chimney (Christos, 2010) 
Table 1. Schematic of gasification process (comparison of various schemes) (Nagel, 2008)

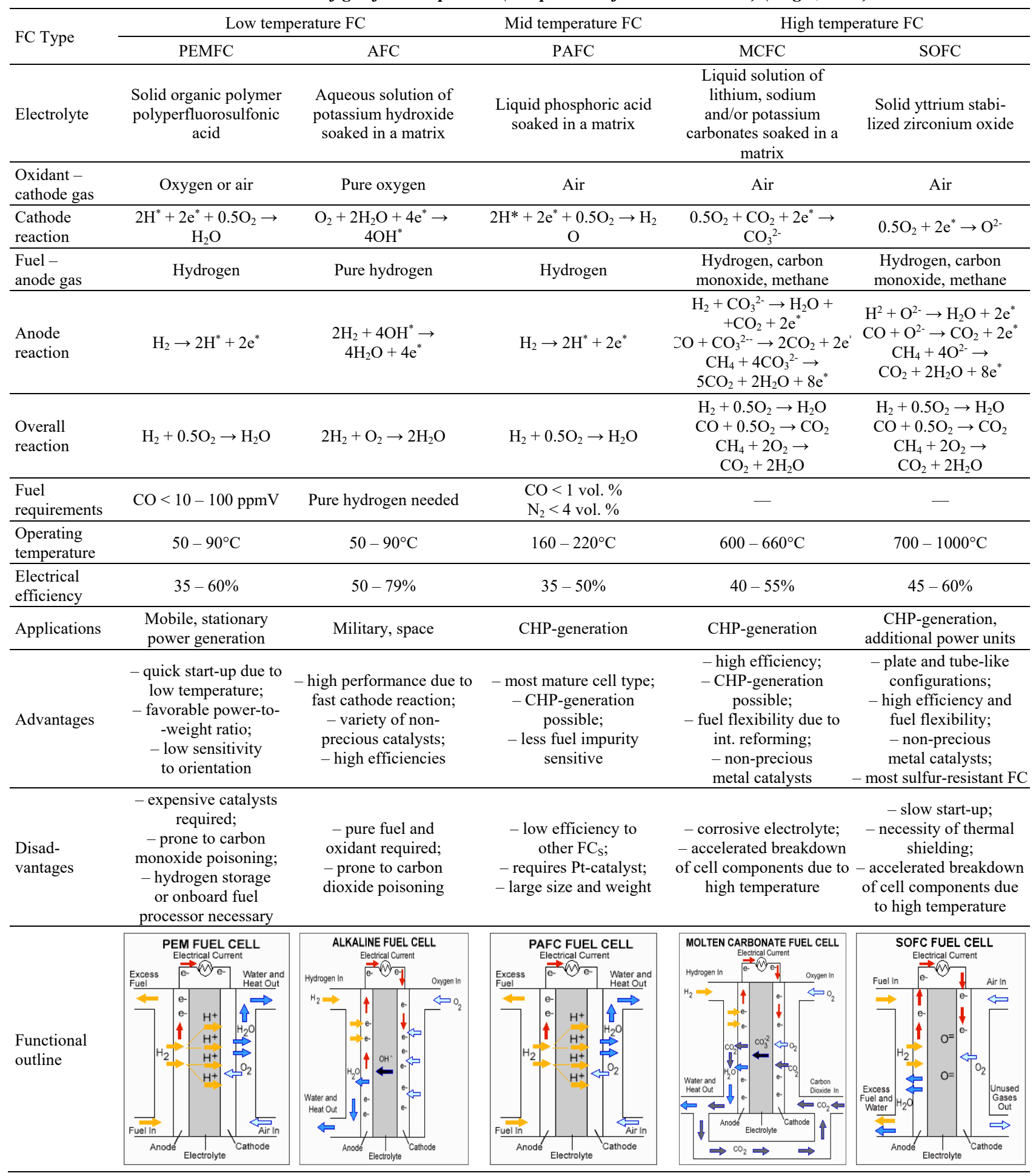

The chimney efficiency is:

$$
\eta=\frac{h}{C_{p}\left(T_{2}-T_{1}\right)}
$$

and since the Carnot efficiency is $\left(T_{2}-T_{1}\right) / T_{2}$, the resultant efficiency becomes $h /\left(C_{p} T_{1}\right)$,

where:

$$
\begin{aligned}
& C_{p} \text { - specific heat; } \\
& h \text { - height of air column; } \\
& T_{2} \text { - working temperature; } \\
& T_{1} \text { - ambient temperature (sink); } \\
& \eta \text { - efficiency. }
\end{aligned}
$$

Coupled with other losses, the efficiency is less than $1 \%$ in practice. One may also look at the "economic efficiency", i.e. the internal rate of return for payback.

According to Al-Dabbas (Al-Dabbas, 2011), an area of $46000 \mathrm{~m}^{2}$ can yield $50 \mathrm{KW}$. At incident solar energy of $1 \mathrm{KW} / \mathrm{sqm}$, this gives an efficiency of $1 \%$, and at peak incidence of $5 \mathrm{KW} / \mathrm{sqm}$, efficiency of $0.02 \%$. Also, costs of maintenance and salaries would go up geometrically, increasing the estimates given. The extreme desert cold at night however will require thermal mass to offset it and allow for fast startup during the day, which is not mentioned. Estimates depending on the interest rate show 
amortization for $25-40$ years with high per unit costs compared to existing technologies (Al-Dabbas, 2011). For 40 years' time, the cost per KWh is 0.25 to 0.40 Euro for amortizations of 6 to $10 \%$ (Fig. 5).

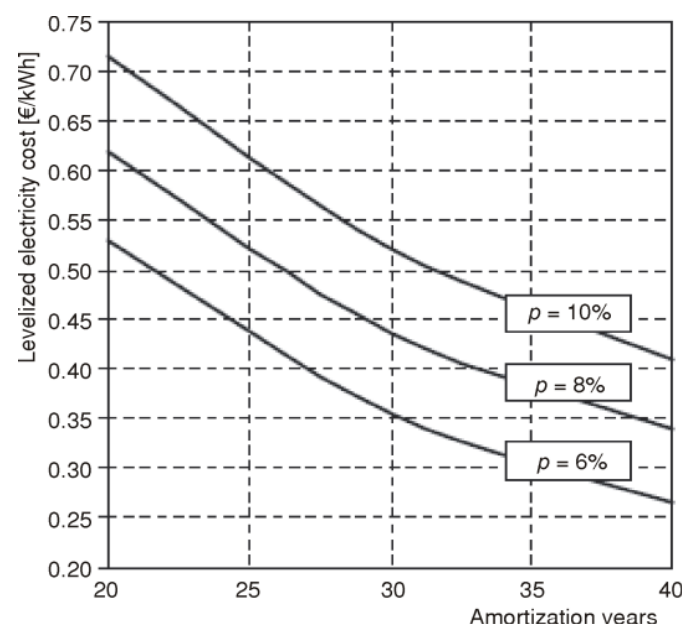

Figure 5. Influence of amortization on unit cost (Al-Dabbas, 2011)

A comparison of various technologies from (Christos, 2010) is given below in Table 2 .

Table 2. A cost comparison of electricity generating technologies

\begin{tabular}{|c|c|c|c|}
\hline $\begin{array}{c}\text { MWh } \\
\text { direct } \\
\text { production } \\
\text { cost } \\
\text { in EURO }\end{array}$ & $\begin{array}{l}\text { Fuel or method } \\
\text { of electricity } \\
\text { generation }\end{array}$ & $\begin{array}{l}\text { Invest- } \\
\text { ment in } \\
\text { EURO } \\
\text { per pro- } \\
\text { duced } \\
\text { MWh/year }\end{array}$ & $\begin{array}{c}\text { Mode of } \\
\text { operation } \\
\text { and capacity } \\
\text { factor }\end{array}$ \\
\hline $55-60$ & $\begin{array}{l}\text { Coal fired (not } \\
\text { including carbon } \\
\text { emission penalties) }\end{array}$ & 200 & $\begin{array}{l}\text { Combined } \\
\text { cycle base } \\
\text { load } 85 \%\end{array}$ \\
\hline $80-100$ & $\begin{array}{l}\text { Coal fired with CCS } \\
\text { (carbon capture } \\
\text { and storage) }\end{array}$ & $300-400$ & $\begin{array}{l}\text { Combined } \\
\text { cycle base } \\
\text { load } 85 \%\end{array}$ \\
\hline $60-65$ & $\begin{array}{l}\text { Natural gas fired } \\
\text { (not including carbon } \\
\text { emission penalties) }\end{array}$ & 150 & $\begin{array}{l}\text { Combined } \\
\text { cycle } 85 \%\end{array}$ \\
\hline $65-75$ & Nuclear fission & $400-450$ & Base load 95\% \\
\hline 60 & Wind parks onshore & 500 & Intermittent $30 \%$ \\
\hline 75 & Wind parks offshore & 650 & Intermittent $30 \%$ \\
\hline 180 & $\begin{array}{l}\text { Concentrating } \\
\text { Solar CSP }\end{array}$ & 2000 & $\begin{array}{l}\text { Continuous } \\
\text { with thermal } \\
\text { storage } 30 \%\end{array}$ \\
\hline 280 & Photo voltaic PV & 3000 & $\begin{array}{l}\text { Intermittent } \\
15-17 \%\end{array}$ \\
\hline 155 & $\begin{array}{l}\text { Solar chimney } \\
\text { concrete }\end{array}$ & $\sim 2000$ & $\begin{array}{l}\text { Continuous } \\
\sim 50 \%\end{array}$ \\
\hline$\sim 60$ & $\begin{array}{l}\text { Floating solar } \\
\text { chimney }\end{array}$ & $\sim 500$ & $\begin{array}{l}\text { Continuous } \\
\sim 50 \%\end{array}$ \\
\hline $55-75$ & Biomass & $500-700$ & $\begin{array}{c}\text { Continuous } \\
85 \%\end{array}$ \\
\hline $50-70$ & Geothermal & $500-800$ & $\begin{array}{c}\text { Continuous } \\
90 \% \\
\text { (limited } \\
\text { resource) }\end{array}$ \\
\hline $50-60$ & Hydroelectric & $500-800$ & $\begin{array}{l}\text { Continuous } \\
\text { (load } \\
\text { following, } \\
\text { limited } \\
\text { resource) }\end{array}$ \\
\hline
\end{tabular}

\subsection{Self-gasification from biomass}

Biomass self-gasification has been reported by Van Rossum (Rossum, Nanou, Swaaij, \& Kersten, 2013), where the heat released by methanation is applied for the heat required for gasification. Exxon is reported to have used it in the 80's, in high pressure coal gasification. Full syngas cycle of biomass self-gasification is presented in Figure 6.

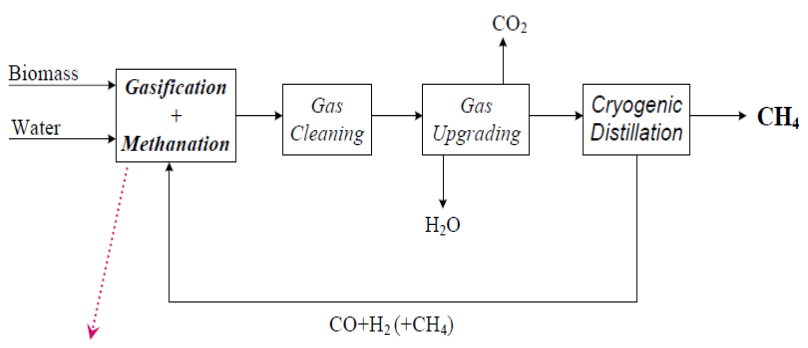

Figure 6. Full syngas cycle

J.D. Mackaluso (2007) has described bio catalysts for producing syngas which then can be processed into alcohol for fuel. The advantage is in using waste which would otherwise be dumped into the ocean or landfills.

\section{FUTURE STUDIES AND AVENUES OF RESEARCH}

It may be possible to invoke the genetic modification of microbes to directly excrete hydrocarbons. Turning water, photonic energy and carbon dioxide into hydrocarbons is a very old process developed by nature, which uses chlorophyll. Perhaps more useful than solid carbohydrates, would be a liquid hydrocarbon that could directly be put to use as fuel. Algae are known to efficiently convert carbon dioxide into fatty acids, and similarly potato plants into carbohydrates. Converting this potato starch into alcohol is a long and expensive process. There has been a search for microorganisms that could do this (Ethanol Fermentation, 2017). Alternatively, sugars can be turned into alcohol, but again there are attendant costs. Much more attractive and useful would be a way to convert raw materials directly into hydrocarbon fuels. Apart from microorganisms, mobile robots are being proposed that would "eat" garbage and unwanted plants and convert these into hydrocarbon fuel forms (Pavlus, 2010).

The direct conversion of cellulose to alcohol (cellulolysis) using lignocellulose (wood cellulose containing lignin a component of wood), has been researched at Argonne Labs (The Bioenergy Technologies Office..., 2017). The process depends on cellulase enzymes produced by bacteria. Saccharomyces cerevisiae, Zymomonas mobilis, E. Coli, are some bacteria targeted for bio engineering to produce ethanol via the cellulosis route. One way to obtain hydrogen from syngas is through the use of the bacterium Rhodospirillum rubrum. Rhodospirillum rubrum is a photosynthetic proteo-bacterium that converts syngas to hydrogen through a process known as the water gas shift reaction (Najafpour, Younesi, \& Mohamed, 2004; Younesi, Najafpour, Ku Ismail, Mohamed, \& Kamaruddin, 2008) have performed multiple experiments to test the ability of Rhodospirillum rubrum to convert syngas. 
Producer gas has been applied as a raw material for bacterial conversion to ethanol also, using the bacteria Clostridium Ljungdahlii, which ingests $\mathrm{CO}, \mathrm{CO}_{2}$ and $\mathrm{H}_{2}$ producing ethanol and water. This process involves gasification, fermentation and distillation to yield alcohol. The alternative is to use a catalytic reactor. Catalysis involves intermediate compounds that get involved in the reaction but are unchanged in composition at the end.

The physical and chemical parameters affecting fermentation of cellulose has been studied by various groups (Armstrong \& Martin, 1983; Senthilkumar \& Gunasekaran, 2005). Another bacteria acetivibro celluloyticus produces acetate, ethanol, water and carbon dioxide.

Recently, groups have tried to bioengineer bacteria to give oil for fuel directly. The group LS9 with UC Berkeley has engineered a bacterium to make enzymes to convert biomass into diesel oil (Bourzac, 2010). A recent US Patent No. 7794969 uses cyanobacteria to produce n-alkanes (Reppas \& Ridley, 2010).

The end is not in sight, and clearly microorganisms exist or can be modified to excrete oils which can be used as fuels, possible without further processing. However, the overall effect on the effect on life on the planet and the ecology and environment must be carefully evaluated before attempting such bioengineering on a large scale in order to satiate the need of some industrial groups which have stuck to old designs for motive engines. The alternative would be to invest in alternative designs for motive power converters.

The internal combustion engine was a byproduct of the Industrial revolution and the industrialization of the Midwest USA, with resultant mass migrations, prior to which electric cars, steam cars and other variants were in vogue in the early $20^{\text {th }}$ century. In fact, the steam engine served Indian railroads for well over a century before the diesel engines took over. Hence one must not get carried away by the demons of science and finance and attempt to change the natural order of nature and life by introducing artificial genetic alterations.

In order to maintain sustainable development in consonance with International efforts and agreed norms, it is essential that efforts to reengineer life forms, regardless of good motives be examined carefully as there can be repercussions in the long run.

In conclusion an ongoing debate is raging amongst various international pundits. It is about the pros and cons of the link between pollution and economic growth. It was suggested in a nutshell, that economic growth alone would take care of the environment after a certain level of prosperity was reached. The idea is a fall out of the Environmental Kuznets Curve (EKC). It is also recognized that depletion of resources from LDC's is an important effect because It is rare for natural resources and capital obtained in this way by pirating resources of LDC's by more developed countries to be reinvested in a sustainable way (Grossman \& Krueger, 1991; Barbier, 1997). It is perhaps one reason why the developed countries refuse to sign the Kyoto and other protocols, believing that nature will eventually take care of itself. The Kusznet's Curves for EEC, US show the downturn, but the downturn has not occurred so far for India and China.

\section{FUTURE EFFORTS IN BIOTECHNOLOGY}

A primary necessary step in the production of second generation biofuels is through syngas, from biomass. There are two major approaches.

The first is by fluidized bed gasification of biomass to fuel gas at approximately $900^{\circ} \mathrm{C}$. This option requires almost no biomass pre-treatment, the product gas however needs downstream catalytic upgrading. Reforming the hydrocarbons to syngas is done catalytically. Such gasification technology has already been demonstrated with biomass for generating heat and/or electricity (Nizetic, Ninic, \& Klarin, 2008; Kempegowda, Tran, \& Skreiberg, 2011).

Second is by entrained flow gasification at high temperature to produce syngas without methane or other hydrocarbons $\left(1000-1300^{\circ} \mathrm{C}\right)$, with sufficient catalytically active components like $\mathrm{K}$ or $\mathrm{Na}$.

Flash pyrolysis: biomass is liquefied to oil/char slurry, which can be atomized in an entrained flow gasifier: the high-energy density slurry can also be transported and processed at a central facility.

Torrefaction: biomass is thermally treated at $250-$ $300^{\circ} \mathrm{C}$ to produce brittle and pulverizable fuel. This can be done on the site, but also before transporting the solid fuel. The latter is attractive since torrefied biomass pulverizes easily; subsequent pelletisation consumes relatively little energy. The torrefied biomass pellet has a high energy density and thus offers economic gains in transportation. Biomass is converted at $600-900^{\circ} \mathrm{C}$ into gas, with significant amounts of small char particles entrained with it. The mixture is directed to the high temperature entrained flow gasifier to convert it to syngas. This combination has a very high efficiency and allows the feeding of conventional chips.

Other schemes could be developed integrating these concepts to produce bio-syngas. From bio-syngas one can synthesize different types of biofuels like FischerTropsch fuels, methanol, DME, mixed alcohols, including pure hydrogen. Extensive gas cleaning and conditioning is required in all these applications.

In one process (Henstra, Sipma, Rinzema, \& Stams, 2007), waste products and various feedstocks convert into syngas. Then, the bacterium Clostridium Ljungdahlii is exposed to syngas and performs fermentation producing ethanol in the process. The ethanol is then extracted by distillation of the mixture. In addition to producing ethanol, BRI plants also generate electricity. Prior to applying Clostridium Ljungdahlii, cooling of the syngas is required; and. heat released during cooling is used to generate electricity. It is claimed that up to 85 gallons of ethanol for every ton of biomass and up to 150 gallons for every ton of hydrocarbon-rich material are converted (Henstra, Sipma, Rinzema, \& Stams, 2007). Another less known area of current interest in the field of renewable energy, is wave energy harvested from ocean currents and waves (Uihlein \& Magagna, 2016).

\section{CONCLUSIONS}

Apart from nuclear energy, the alternative energy technologies all derive from solar energy, and in a sense even fossil fuels are derived from archaic biomass produced bysolar energy. It is seen that inefficient conver- 
sion technologies like the solar chimney can produce sufficient power provided sufficient infrastructure and capital expenditure is applied. However, developing large amounts of capital assets and infrastructure involves producing large amounts of energy, in terms of the carbon footprint, which will take longer to recover, apart from recovery of capital. The other technologies that use readily available biomass and fossil fuel require lower capital asset development and perhaps lower technology and energy expenditure in manufacture of engines and generating stations. The total energy budget and outlay needs to be looked at and the payback assessed over the life of the generator, along with capital payback to get a fair and full estimate of the relative merits amongst the various alternatives. Solar chimneys are the lowest efficiency alternatives; however, the input energy is free and inexhaustible. On the other hand, the Stirling and Brayton engines have the highest thermodynamic (Carnot) efficiencies, yet have not been developed to the extent of the Diesel and two stroke Internal combustion engines which are among the major polluting sources today. An alternative efficiency (internal rate of return), or economic efficiency, may also be considered.

\section{ACKNOWLEDGEMENTS}

This work was presented at the International Conference on Environmental Design and Innovation, Amman Jordan in May 2016. The author thanks the organizers and Al-Zaytoona University for local hospitality.

\section{REFERENCES}

Al-Dabbas, A. (2011). A Performance Analysis of Solar Chimney Thermal Power Systems. Thermal Science, 15(3), 619-642. https://doi.org/10.2298/tsci101110017a

Armstrong, D.W., \& Martin, S.M. (1983). Bacterial Fermentation of Cellulose: Effect of Physical and Chemical Parameters. Biotechnology and Bioengineering, 25(11), 2567-2575. https://doi.org/10.1002/bit.260251107

Bensah, E.C., \& Brew-Hammond, V. (2008). Biogas Effluent and Food Production in Ghana. In National Conference of Ghana Society of Agricultural Engineering. Kumasi, Ghana: GSAE.

Bourzac, K. (2010). Bacteria Make Diesel from Biomass, pp. 1. Retrieved from https://www.technologyreview.com/s/ 417263/bacteria-make-diesel-from-biomass/

Campen, B., Guidi, D., \& Best, G. (2000). Solar Photovoltaics Energy for Sustainable Agricultural and Power Development. Rome: Food and Agriculture Organization of the United Nations.

Carey, J. (2012). Is Global Warming Happening Faster Than Expected? Scientific American, pp. 22. Retrieved from https://www.scientificamerican.com/article/is-globalwarming-happening-faster-than-expected/

Christos, D. (2010). Floating Solar Chimney Technology. Solar Energy. Croatia: INTECH. https://doi.org/10.5772/8069

De Laat, A.T.J., de Gouw, J.A., Lelieveld, J., \& Hansel, A. (2001). Model Analysis of Trace Gas Measurements and Pollution Impact during INDOEX. Journal of Geophysical Research: Atmospheres, 106(D22), 28469-28480.

https://doi.org/10.1029/2000jd900821
Ethanol Fermentation. (2017). Retrieved from https://en.wikipedia.org/wiki/Ethanol_fermentation

Grossman, G., \& Krueger, A. (1991). Environmental Impacts of a North American Free Trade Agreement. Cambridge: Cambridge Press. https://doi.org/10.3386/w3914

Mackaluso, J.D. (2007). The Use of Syngas Derived from Biomass and Waste Products to Produce Ethanol and Hydrogen. Basic Biotechnology Journal, (3), 98-103.

Mahin, D.B. (1983). Bioenergy from Crop Residues. Washington: BST, Office of Energy.

Nagel, F.P. (2008). Electricity from Wood through the Combination of Gasification and Solid Oxide Fuel Cells Systems Analysis and Proof-of-Concept. Doctoral Thesis. Swiss Federal Institute of Technology.

Najafpour, G., Younesi, H., \& Mohamed, A.R. (2004). Effect of Organic Substrate on Hydrogen Production from Synthesis Gas using Rhodospirillum Rubrum, in Batch Culture. Biochemical Engineering Journal, 21(2), 123-130. https://doi.org/10.1016/j.bej.2004.06.001

Pavlus, J. (2010). A Wandering, Plant-Eating Robot. Scientific American, pp. 21. Retrieved from https://www.scientificamerican.com/article/a-wandering-plant-eating-robot/

Reppas, N.B., \& Ridley, C.P. (2010). Methods and Compositions for the Recombinant Biosynthesis of n-Alkanes. Patent No. 7794969, United States.

Rossum, G., Nanou, P., Swaaij, W., \& Kersten, S. (2013). BioEnergy IV: Innovations in Biomass Conversion for Heat, Power, Fuels and Chemicals. Enschede: University of Twente.

Santos Bernardes, M.A. (2010). Solar Chimney Power Plants Developments and Advancements. Solar Energy. Croatia: INTECH. https://doi.org/10.5772/8068

Senthilkumar, V., \& Gunasekaran, P. (2005). Bioethanol Production from Cellulosic Substrates: Engineered Bacteria and Process Integration Challenges. Journal of Scientific \& Industrial Research, 64(11), 845-853.

Sridhar, G., Sridhar, H.V., Dasappa, S., Paul, P.J., Rajan, N.K.S., \& Mukunda, H.S. (2005). Development of Producer Gas Engines. Proceedings of the Institution of Mechanical Engineers, Part D: Journal of Automobile Engineering, 219(3), 423-438. https://doi.org/10.1243/095440705x6596

The Bioenergy Technologies Office: Advancing a Thriving and Sustainable Bioeconomy Fueled by Innovative Technologies. (2017). Retrieved from https://energy.gov/bioenergy

Uihlein, A., \& Magagna, D. (2016). Wave and Tidal Current Energy - A Review of the Current State of Research Beyond Technology. Renewable and Sustainable Energy Reviews, (58), 1070-1081. https://doi.org/10.1016/j.rser.2015.12.284

Wald, M. (2010). Gas from Trash. Scientific American, pp. 24. Retrieved from https://www.scientificamerican.com/article/ gas-from-trash/

Wood Gas as Engine Fuel. (1986). Rome: Food and Agriculture Organization of the United Nations.

Younesi, H., Najafpour, G., Ku Ismail, K.S., Mohamed, A. R., \& Kamaruddin, A.H. (2008). Biohydrogen Production in a Continuous Stirred Tank Bioreactor from Synthesis Gas by Anaerobic Photosynthetic Bacterium: Rhodopirillum Rubrum. Bioresource Technology, 99(7), 2612-2619. https://doi.org/10.1016/j.biortech.2007.04.059 


\section{ABSTRACT (IN UKRAINIAN)}

Мета. Надати і порівняти різні види відновлюваної енергії з урахуванням енергетичної кризи, пов'язаної 3 глобальним потеплінням і виснаженням викопних джерел палива, що призводить до викидів вуглекислого газу, який є головним джерелом забруднення атмосфери й поглинання радіації.

Методика. При огляді літературних джерел та аналізі переваг і недоліків конкуруючих технологій необхідно враховувати капітальні й експлуатаційні витрати, а також вуглецевий слід. Рідкі види палива відрізняються більш високою питомою енергією по масі в порівнянні з сонячними панелями або термокомпенсаторами. Не можна недооцінювати той факт, що виробництво рідкого палива передбачає наявність громіздкого очисного й переробного обладнання, робота якого збільшує вуглецевий слід.

Результати. Генераторний газ і бактеріальні двигуни пропонуються в якості способу зменшення забруднення та економічного отримання електричної енергії. Отримання електроенергії на геотермальних і гідроелектростанціях, а також на станціях, що працюють на вугіллі чи біомасі, передбачає низькі витрати на експлуатацію. Однак, при цьому не враховуються витрати на боротьбу з вуглецевими викидами. Сонячні електростанції аеродинамічного типу при малому механічному ККД відрізняються низькими експлуатаційними витратами і практично не забруднюють навколишнє середовище. Модифіковані двигуни внутрішнього згоряння, що дозволяють отримувати генераторний газ і спирт, можуть сприяти зменшенню вуглецевих викидів.

Наукова новизна. Багато вчених розглядають проблеми отримання енергії й підвищення механічного ККД. Необхідно вдосконалювати бактеріальні двигуни, свого роду хімічні фабрики, робота яких ще не до кінця зрозуміла з точки зору класичної термодинаміки. Оцінюючи різні технології, слід виходити з окупності інвестицій, оскільки вона включає капітальні витрати, які зазвичай не враховуються при розрахунках механічного ККД.

Практична значимість. Скорочення лісового покриву планети, який є поглиначем парникових газів, призводить до глобального потепління. Якщо двигуни мільйонів машин по всьому світу перевести з бензину на альтернативні види палива, скоротяться парникові викиди й сповільняться темпи глобального потепління.

Ключові слова: генераторний газ, біогаз, глобальне потепління, вуглецевий слід, ККД

\section{ABSTRACT (IN RUSSIAN)}

Цель. Представить и сравнить различные виды возобновляемой энергии с учетом энергетического кризиса, связанного с глобальным потеплением и истощением ископаемых источников топлива, что приводит к выбросам углекислого газа, который является главным источником загрязнения атмосферы и поглощения радиации.

Методика. При обзоре литературных источников и анализе преимуществ и недостатков конкурирующих технологий необходимо учитывать капитальные и эксплуатационные затраты, а также углеродный след. Жидкие виды топлива отличаются более высокой удельной энергией по массе по сравнению с солнечными панелями или термокомпенсаторами. Нельзя недооценивать тот факт, что производство жидкого топлива предполагает наличие громоздкого очистного и перерабатывающего оборудования, работа которого увеличивает углеродный след.

Результаты. Генераторный газ и бактериальные двигатели предлагаются в качестве способа уменьшения загрязнения и экономичного получения электрической энергии. Получение электроэнергии на геотермальных и гидроэлектростанциях, а также на станциях, работающих на угле или биомассе, предполагает низкие расходы на эксплуатацию. Однако, при этом не учитываются расходы на борьбу с углеродистыми выбросами. Солнечные электростанции аэродинамического типа при малом механическом КПД отличаются низкими эксплуатационными расходами и практически не загрязняют окружающую среду. Модифицированные двигатели внутреннего сгорания, позволяющие получать генераторный газ и спирт, могут способствовать уменьшению углеродистых выбросов.

Научная новизна. Многие ученые рассматривают проблемы получения энергии и повышения механического КПД. Необходимо совершенствовать бактериальные двигатели, своего рода химические фабрики, работа которых еще не до конца понятна с точки зрения классической термодинамики. Оценивая различные технологии, следует исходить из окупаемости инвестиций, поскольку она включает капитальные затраты, которые обычно не учитываются при расчетах механического КПД.

Практическая значимость. Сокращение лесного покрова планеты, который является поглотителем парниковых газов, приводит к глобальному потеплению. Если двигатели миллионов машин по всему миру перевести с бензина на альтернативные виды топлива, сократятся парниковые выбросы и замедлятся темпы глобального потепления.

Ключевые слова: генераторный газ, биогаз, глобальное потепление, углеродный след, КПД

\section{ARTICLE INFO}

Received: 13 October 2017

Accepted: 23 November 2017

Available online: 27 November 2017

\section{ABOUT AUTHORS}

Rahul Basu, Doctor of Philosophy, Professor of the Mechanical Engineering Department, Adarsha Institute of Technology (Visvesvaraya Technological University), Sy. No. 73, Lingadheera Gollahalli, Kundana Hobli, Devanahalli Taluk, 562110, Bangalore, India. E-mail: raulbasu@gmail.com 